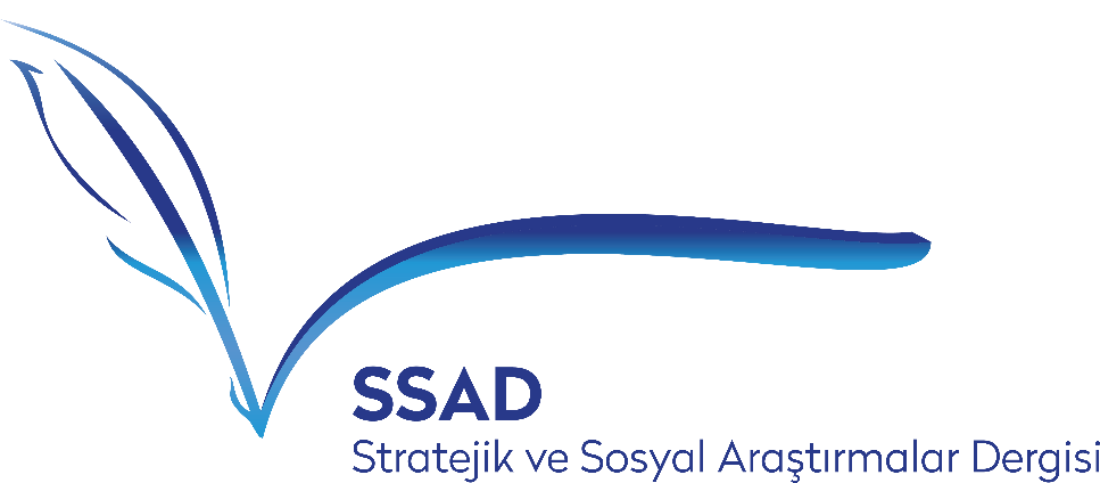

ISSN: 2587-2621

Volume 3 Issue 3, November 2019

ORCID ID: 0000-0003-0004-2756

Makale Gönderim Tarihi: 06.09.2019

Makale Kabul Tarihi: 13.10.2019

\title{
ÖRGÜTSEL ATALET KAVRAMINA TEORİK BİR BAKIŞ*
}

\section{A Theoretical Overview to The Concept of Organizational Inertia}

\author{
Ahmet TÜRKAN \\ $\ddot{O} \check{g} r$. Gör. \\ Uşak Üniversitesi, \\ Adalet Meslek Yüksekokulu, \\ ahmetturkan@usak.edu.tr
}

\author{
Yusuf ESMER \\ Dr. Ögrr. Üyesi \\ Bayburt Üniversitesi, \\ Uygulamalı Bilimler Fakültesi \\ yesmer@bayburt.edu.tr
} * Bu çalışma 2-4 Mayıs 2019 tarihinde Rize'de düzenlenen Uluslararası Adalet Kongresi'nde sunulan bildirinin
genişletilmiş halidir. 
Öz: "Atalet” yalnızca bireylerin yaşamında var olan bir olgu değildir. Aynı zamanda örgütlerin yaşamında da yer alan ve örgütlerin yaşamını olumsuz etkileyen etkenlerin başında gelmektedir. Örgütlerde yer alan atalet "örgütsel atalet" olarak kavramsallaştırılmaktadır. Örgütsel atalet; örgütlerin işlemez hale gelmeleri, kendilerini yenileyememeleri, değişimlere ayak uyduramamaları, harekete geçememeleri olarak tanımlanabilir. Örgütsel atalet, örgütlerin değişiminin önünde büyük bir engel olarak görülmektedir. Bu bağlamda başta stratejik yönetim olmak üzere örgütlerin birçok işlevini olumsuz etkileyerek örgütlerin rekabet ortamında ayakta kalamamalarına ve başarısız olmalarına neden olmaktadır. Bu nedenle örgütsel atalet üzerinde durulması ve irdelenmesi gereken önemli bir kavramdır. Bu çalışmanın amacı örgütsel atalet kavramını teorik olarak inceleyerek önemini, nedenlerini, olumsuz etkilerini ve alınabilecek önlemleri ortaya koymaktır. $\mathrm{Bu}$ amaç doğrultusunda çalışmada örgütsel atalet kavramı ile ilgili yapılmış güncel çalışmalar incelenerek konunun teorik çerçevesi çizilmeye çalışılmaktadır. Araştırma sonucunda, güçlü bir örgüt kültürü, adil yönetim, yenilik, işbirliği, öğrenme ve sinerjik liderliğin örgütsel ataleti engellediği vurgulanmaktadır. Örgütsel ataletin üstesinden gelinmesi, örgütün yeniden harekete geçmesini sağlayarak örgüt performansını artıracak dolayısıyla örgütsel başarıya olumlu yansıyacaktır.

Anahtar kelimeler: Atalet, Örgütsel Atalet, Örgütsel Ataletin Üstesinden Gelme

\begin{abstract}
Inertia is not a phenomenon that exists only in the lives of individuals. At the same time, it is one of the factors that affect the life of organizations and also take place in the life of organizations. The inertia in organizations is conceptualized as organizational inertia. Organizational inertia; organizations cannot be processed, they cannot renew themselves, they cannot keep up with changes, they cannot act. Organizational inertia is seen as a major obstacle to the change of organizations. In this context, it has a negative effect on many functions of organizations, especially strategic management, causing organizations to survive and fail in a competitive environment. For this reason, organizational inertia is an important concept that needs to be emphasized and examined. The aim of this study is to examine the concept of organizational inertia theoretically and its importance, causes, negative effects and measures to be taken. For this purpose, the theoretical framework of the subject is studied by examining the current studies on the concept of organizational inertia. As a result of the research, it is emphasized that a strong organizational culture, fair management, innovation, cooperation, learning and synergistic leadership prevent organizational inertia. Overcoming organizational inertia will increase the organization's performance by enabling the organization to react again and thus will reflect positively on organizational success.
\end{abstract}

Keywords: Inertia, Organizational Inertia, Overcoming Organizational Inertia

\title{
GİRiş
}

Günümüzde bireylerin ve örgütlerin başarısını engelleyen faktörlerin başında atalet kavramı gelmektedir. Atalet, insan kaynağının verimli bir şekilde kullanılmasında hayati öneme sahip bir takım içsel durumları yansıtmaktadır. Bunlar bireylerde başlayan ve örgütün geneline yayılabilen; isteksizlik, durgunluk, eylemsizlik, tembellik, üşengeçlik, uyuşukluk, depresiflik gibi durumlardır (Kaya vd., 2018: 41; Çankaya ve Demirtaş, 2010: 1). Atalet kavramı içerisinde durağanlık, gaflet, delalet, erteleme isteği, mazeret bulma ve tembellikten oluşan duygusal durumları barındırmaktadır (Soysal, 2010: 17). Dil bilimi açısından atalet kavramı "atıl" sözcüğünden türetilmiştir (Arlı vd., 2012: 75). Atıl sözcüğü ise "aylak, işe yaramaz, etkisiz, tembel" anlamlarına gelmektedir (TDK, 2006: 1). Osmanlı lügat sözlüğünde ise atıl sözcüğü "boş durma, tembellik, işsizlik" olarak ifade edilmektedir (Yeğin ve Badıllı, 1981: 135). Bu bağlamda atalet; boş durmak, eyleme geçememek, tembellik etmek olarak tanımlanabilmektedir. İnsan ve onun örgütlendiği sosyal birimin büyüklügüne göre atalet; bireysel ve örgütsel olmak üzere iki farklı şekilde ele alınmaktadır. Bireysel atalet; kazanılmış deneyim ve bilgilere saplantı düzeyinde bağlılık, değişime karşı ilgisizlik ve direnç gösterme, görevleri önemseme ve hakkıyla yerine getirmeme, tembellik etme şeklinde görülmekte iken, örgütsel atalet ise değişimleri zamanında yakalayamama, değişime ve yeniliğe direnme, mevcut durumu sürdürme şeklinde kendisini göstermektedir (Kinnear ve Roodt, 1998: 44). Bireysel atalet, fiziksel atalet ve psikolojik atalet olmak üzere ikiye ayrılmaktadır (Fettahlığlu vd., 2018: 45). 
Fiziksel atalet, bireyi fiziksel olarak hantallaştıran ve hareketsizliğe iten güç iken, psikolojik atalet ise bireyin zihinsel anlamda tembellik yaşamasıdır (Soysal, 2010: 18). Yapılan araştırmalar ataletin çoğunlukla psikolojik olduğu göstermektedir (Atalay, 2013: 4). Psikolojik atalet, fizyolojik ataleti besleyen bir katalizördür. Psikolojik ataletin düşünsel dengeyi, fizyolojik ataletin ise bedensel dengeyi olumsuzluk bir şekilde etkilediği söylenebilir (Fettahlıŏlu vd., 2018: 45). Bireysel ataletin birçok nedeni bulunmaktadır. Umursamama, mükemmeliyetçilik, kişilik yapısı, erteleme, yetersizlik, iş tatminsizliği, başarısızlık korkusu ve yabancılaşma bu nedenlerden bazılarıdır (Cırcır, 2006: 12). Eski alışkanlık, düşünce ve değer yargılarından vazgeçilememesi sonucu ortaya çıkan bir sorun olarak görülen atalet, bireylerin ve örgütlerin yaşamlarında oluşan veya ilerde ortaya çıkabilecek yeniliklere mesafeli davranmak, bunları kabullenmemek ve bu nedenle değişime uyum sağlamayı göze almamaktır (Çankaya, 2010: 66). Bu bağlamda örgütlerin gelişiminin önünde önemli bir engel olarak görülen ataletin örgütsel düzeyde incelenmesi gerekmektedir.

$\mathrm{Bu}$ çalışmanın amacı örgütsel atalet kavramını teorik olarak inceleyerek önemini, nedenlerini, olumsuz etkilerini ve alınabilecek önlemleri ortaya koymaktır. Bu amaç doğrultusunda çalışmada örgütsel atalet kavramı ile ilgili yapılmış güncel çalışmalar incelenerek konunun teorik çerçevesi çizilmeye çalışılmıştır. Çalışmada örgütsel ataletin üstesinden gelmeye yönelik öneriler sunulmuştur.

\section{1. Örgütsel Atalet}

$\mathrm{Bu}$ kısımda örgütsel atalet kavramı, nedenleri, olumsuz etkileri ve örgütsel ataletin üstesinden gelmenin yolları açıklanmaktadır.

\section{1. Örgütsel Atalet Kavramı}

İş yaşamında bir örgütün büyümesinin ve varlığını devam ettirmesinin en önemli itici gücü değişime ayak uydurması ve bu değişime katılım sağlamasıdır. Ancak değişimi zorlaştıran ve örgüt gelişimini, başarısını, performansını ve verimliliğini olumsuz etkileyen etkenlerin başında örgütsel atalet gelmektedir (İbrahimoğlu vd., 2015: 615). Biçimsel anlamda örgütsel atalet, bir örgütün çevresinde meydana gelen değişimlere cevap vermekten çok, kendi içsel değişiminde 1 srarcı olması ve bunu korumak istemesi olarak ifade edilmektedir (Arlı vd., 2012: 75). Bu süreçte örgüt içerisinde kişisel alışkanlıklar ve bağl1lıkların devam etmesi nedeniyle değişim ve gelişime karşı direnç gösterildiği görülmektedir. Bu nedenle örgütsel yapının, değişime engel ve mevcut durumu koruyan ve kollayan bir sürece doğru devşirilmesi örgütsel atalet olarak değerlendirilmektedir. Atalete giren bir örgüt, mevcut yeteneklerini kısıtlamayarak ortaya çıkan firsatları tam olarak değerlendirememekte ve yeni risklerin oluşumuna zemin hazırlamaktadır (Soysal, 2010: 20). Bu bağlamda, bireylerin yaşamlarında alışkanlıklarını, düşüncelerini ve değer yargılarını kolayca bırakmak istememeleri ve de buna karşı direnmeleri örgütsel atalete neden olmaktadır (Çankaya, 2010: 66). Atalet, örgütleri hantallaştırarak rakiplerinin gerisinde kalmasina sebep olmaktadır (Sekman ve Utku, 2009: 128).

Ataletin hâkim olduğu örgütler, karşılaştıkları firsatları tam olarak değerlendirememekte, yeteneklerinin farkına varamamakta, yeni risklerin oluşumuna zemin hazırlayarak gelişimlerini engellemektedirler (Arlı vd., 2012: 75-76). Örgütlerde atalet, kendiliğinden gerçekleşmemekte, bir dizi aşamaların tamamlanmasının ardından gerçekleşen kemikleşmiş bir yapının örgütü ele geçirmesiyle ortaya çıkmaktadır. Bu aşamalar; algılamama, yorumlamama ya da yanlış yorumlama, uygulamama ve sonuçlandırmama olarak siralanabilir (Sekman ve Utku, 2009: 148).

Örgütsel ataletin, sezgisel atalet ve eylemsel atalet olmak üzere iki türü vardır. Sezgisel atalet, belirsiz çevre koşullarında yaşanabilecek değişimler hakkında yöneticilerin yanlış tahminleri, yöneticilerin başarısız olmaları ve elde edilen bilgilerin faydasız veya örgütün verimliliğine yeterli düzeyde katkısının bulunmadığı durumlarda ortaya çıkmaktadır. Eylemsel atalet ise çevre analizinin 
yapılmasından sonra ortaya çıkmakta ve yönetimin gereken adımları atmakta geç kalması ya da hiçbir tepki göstermemesi durumlarında ortaya çıkmaktadır (Bakan vd., 2017: 24).

Literatürde "örgütsel eylemsizlik" olarak da adlandırılan örgütsel atalet ile ilgili genel bir tanım yapmak gerekirse; örgütlerin işlemez hale gelmeleri, kendilerini yenileyememeleri, değişimlere ayak uyduramamaları, harekete geçememeleri, eylemsiz halde durmaları böylece amaçlarından uzaklaşmaları örgütsel atalet olarak ifade edilebilmektedir.

\section{2. Örgütsel Ataletin Nedenleri}

Örgütsel ataletin birç̧ok nedeni bulunmaktadır. Geleneklere aşırı bağlılık, değişime tepki, başarının ve özgüvenin yanıltma etkisi, öğrenme döngüsünün kesintiye uğramas1 ve örgütün ilerleyen yaş1 bunlardan bazılarıdır. Bu nedenler aşağıda açıklanmaktadır.

- Geleneklere aşırı bağlılık: Gelenekler, toplumda zaman içerisinde tekrarlanmak suretiyle günümüze kadar gelmiş rutin davranışlar ve değişmeyen kalıplardır. Bunlar, örgütlerin değişim ve yeniliklere ayak uydurma eğilimlerinin zayıflamasına ve alışılmışın dişına çıkmalarına engel olmaktadır. Örgüt üyelerinin bu gelenek döngüsünden çıkamaması veya aşırı saplantıları örgütsel atalete neden olmaktadır (Soysal, 2010: 22).

- Değişime tepki: Örgütler çevrelerinin istek ve beklentilerine yanıt verebilmek için; stratejilerini, politikalarını ve yapılarını sürekli değiştirerek, çevreye uyum sağlamak zorundadırlar (Soysal, 2010: 20). Bireyler ve örgütler çoğu zaman ortaya çıkacak yeni bir durumla baş edemeyeceklerini düşündüklerinden veya yeni yükümlülüklere sebebiyet vereceği kaygısıyla, sorumluluk almak istemediklerinden atalet eğilimli davranışlara yönelmektedirler. Bunun temelinde değişikliklerden hoşnut olmama, bilineni tercih etme, riskten kaçınmak, alışkanlıklardan uzaklaşamama veya özgüven eksikliği gibi nedenler bulunmaktadır (Koçel, 2010: 672).

- Başarının ve aşırı özgüvenin yanıltma etkisi: Başarıyla birlikte gelen ego ve özgüven örgüt içerisindeki bireyler arasında "en doğrusunu biz biliriz" düşüncesinin gelişmesine ve örgütte kibre neden olmaktadır (Sekman ve Utku, 2009: 141). Bireylerin kendi işleyişlerinin mükemmel olduğu yönündeki düşünceleri örgütleri atalete doğru yönlendirmektedir. Bu durum örgütlerin stratejilerini ve performanslarını rakipleriyle karşılaştırmasını engellemekte dolayısıyla "örgütlerin birbirlerinden öğrenmesi”" olarak ifade edilen "benchmarking (klyaslama)" gibi bir yönetim tekniğinden habersiz bir şekilde varlıklarını sürdürmelerine neden olmaktadır (Erdem, 2006: 68). Ayrıca bu düşünce örgütlerin yanlışlarını görememelerine ve kendilerini geliştirememelerine neden olmaktadır.

-Ö̆̆renme döngüsünün kesintiye uğramast: Bireysel boyutta söz konusu olan bilgi ataletinin, örgüt kültürüne egemen olması ve örgütsel düzeyde meydana gelmesidir. Bilgi ataleti, bireylerin önceki bilgileriyle yaşamlarını sürdürmeleri ve bu doğrultuda yeni bir bilgiye gereksinim duymadan ve öğrenmeden mevcut durumu korumalarıdır. Başka bir ifade ile bireylerin geçmiş deneyim ve bilgilerini yeterli görüp, yeni bilgi öğrenme noktasında uyuşuk duruş (öğrenme ataleti) sergilemeleridir. Öğrenme yetisini yitiren örgütler, zaman ve enerji tasarrufu sağlamak ve risklerden kaçınmak için, genellikle rutin problem çözme prosedürleri benimseyen bir süreci tercih etmektedirler (Atalay, 2013: 15-16).

-Örgütün ilerleyen yaşı: Örgütler, yaşları ilerledikçe örgüt içinde ve dışında güven tesis eden, olağan uygulamaları örgütsel yapıyla bütünleştirmek istemektedirler. Ancak zamanla geliştirilen ilişkilerle, güç merkezlerinin bir parçası haline gelerek, bir meşruiyet kazanan örgütün değişmesi, yeni uygulamalara adapte olması ve yeniden yapılanması kolay olmamakta ve tüm bunlar örgütün yaşam riskini artırmaktadır (Önder ve Üsdiken, 2007: 144-145). Bu tür örgütlerin yeni yapılar ve süreçler benimseyerek yeniliklere çabucak uyum sağlamaları oldukça zor olmaktadır (Erdil vd., 2010: 22). Diğer yandan, örgüt içerisinde açık, samimi bir ortamın yerine kapalı ve bürokratik bir iklimin 
hâkim olması, iş bölümü-hiyerarşik sınıflamanın aşırı belirgin olması, katı örgüt yapısı ve örgüt içerisinde iletişim yeteneğinin gelişmemesi sayılabilecek diğer nedenlerdir. Özellikle iletişim yeteneğinin gelişmemesi, hem bireylerarası bilgi alışverişini kısıtlaması yönüyle bilgi ataletini arttırması, hem de eylemlerde bağlantısızlık olarak ifade edilebilecek olan, örgüt içinde bireylerin ve bölümlerin koordinasyonunun sağlanamamasına neden olmasıyla ataleti tetikleyen negatif bir etkendir (Çankaya, 2010: 66; Soysal, 2010: 22).

\section{3. Örgütsel Ataletin Olumsuz Etkileri}

Örgütsel ataletin sonuçlarını dolaylı ve dolaysız olarak farklı şekillerde gözlemek mümkündür. Bu sonuçlar hem çalışanları, hem de müşteri ve diğer örgütlerle olan ilişkileri olumsuz etkilemektedir. Ataletin örgütsel düzeyde ilk olarak göze çarpan etkisi, örgütlerin değişimlere ayak uydurma potansiyelini ve rekabet kabiliyetlerini olumsuz etkilemesidir. Rakiplerinin gerisinde kalan örgütün hem sektörel hem de müşteri nezdindeki imajının sarsılacağı kesindir (Kaya vd., 2018: 42).

Örgütsel atalet, zaman içerisinde çalışanların örgütlerinden, yaptıkları işlerden ve hatta kendilerinden soğuyarak yabancılașmalarına neden olmaktadır. İșlerine ve örgüte karșı aidiyet hissinin gelișmemesi örgütsel düzeyde yabancılaşmaya, örgütsel bağlarının gevşemesine ve hatta işten ayrılma eğilimlerinin artmasına neden olmaktadır. Bu durum, örgütlerin maddi ve manevi açıdan maliyetlerini artırmaktadır. Bu nedenle işten ayrılmaların en aza indirilmesi için bu nedenlerin tespit edilmesi ve zamanında önlenmeye çalışılması gerekmektedir. Atalet durumu, örgütsel yapının daha bürokratik bir yapıya bürünmesine neden olmaktadır. Bürokratik örgütlenme biçiminin hâkim olduğu örgütsel yapılarda çalışanların yönetime katılımı sınırlı olmaktadır. Bu durumun örgüt içinde demokratik katılımın sınırlı olmasına yol açmaktadır (Şahlan, 1979: 23). Demokratik iklimin yitirilmesi çalışanların zamanla mutsuz ve duyarsız bir hale gelmesine sebebiyet vermektedir. Bu durum aynı zamanda çalışanların isteksizliğine ve verimsizliğine yol açmaktadır. İşinden veya örgütteki atmosferden tatmin olamayan değerli ve nitelikli elemanlar zamanla örgütten ayrılma yolunu seçmekte ve örgütün yüksek işgücü devir hızıyla karşılaşmasına sebebiyet vermektedir. Ataletin karakteristik özelliği, atıl (boş) kapasite oluşturmasıdır. Örgütün atıl kalması, insan kaynaklarının da atıl kalmasına olabilmektedir. Atıl kalan insan kaynaklarının yapabilecekleri ile yaptıkları arasındaki fark artmaktadır. Bu durum işte kaytarmalara yol açarak çalışanların ellerinden geleni yapmadıkları gibi örgüte zarar vermekten zevk alır hale gelmelerine neden olmaktadır (Sekman ve Utku, 2009: 134-150). Böylelikle örgütsel atalet, çalışanların çevresindeki gelişmelere veya insanlara kuşku, beğenmeme, şüpheyle yaklaşma durumları olarak ifade edilen örgütsel sinizm olgusuna sebebiyet vermektedir (Özen Kutaniş ve Dikili, 2012: 270). Örgütsel atalet, bulaşıcı olması nedeniyle, genellikle birlikte çalışılan diğer örgütlere de bulaştırılarak, onların da zor durumda kalmalarına ve domino taşları gibi sektördeki tüm örgütlerin bu durumdan olumsuz etkilenmesine zemin hazırlamaktadır. Örgütsel atalet, çevreyle uyum sorunu yaşayan bir örgütün çalışanlarının da çevredeki değişimlere uyum kabiliyetinin düşeceği söylenebilmektedir (Sekman ve Utku, 2009: 128150). Bu durum örgütlerin zamanla bulunduğu çevrede yabancılaşmasına yol açmaktadır (Şenturan, 2007: 96). Bu bağlamda örgütsel ataletin bireysel atalete, bireysel ataletin ise yabancılaşmaya neden olduğu ve aslında yabancılaşmanın örgütsel ataletin bireye indirgenerek yeniden tanımlanmış hali olduğu söylenebilir.

Sonuç olarak; örgütsel atalet, örgüt içindeki iletişimin zamanla zayıflamasına, koordinasyon eksikliğine ve beraberinde başarısızlık, verimsizlik, kararsızlık, vizyon ve misyon eksikliği, çalışanları ümitsizliğe düşürmek gibi fizyolojik ve psikolojik kaosun yaşanmasına neden olarak örgütleri başarısız hale getirmektedir (Soysal, 2010: 17). 


\section{4. Örgütsel Ataletin Üstesinden Gelme}

Örgütsel atalet; örgütleri, hareketsizliğe, eylemsizliğe, çöküşe sevk etmektedir. Gücünü zihinsel tembellikten alan bu durum ile mücadele edilmediği takdirde örgütleri içinde bulundukları iş yaşamında atıl bir konuma sürüklemektedir. Bu bağlamda örgütsel atalet durumundan kurtulmak için; bilindik davranış kalıplarından uzak durmak, prosedürleri ve kuralları örgütsel amaçlara uygun düzenlemek ve çevresel değişimlere de duyarlı olmak gerekmektedir. Bu nedenle örgütler, iş zenginleştirme, iş rotasyonu, yetki devri, eğitim ve danışmanlık gibi uygulamalarla örgütsel ataleti zayıflatarak ortadan kaldırabilmektedirler (Soysal, 2010: 23).

Örgütler, bir problem durumunda bunu çözmek için yeni yöntemler bulmak veya denemek yerine, sahip oldukları bilgi ve tecrübeyi kullanarak, zamandan tasarruf ettiklerini böylece yeni bir yöntem denemenin getireceği riskten kaçındıklarını düşünmektedirler. Bu durum aynı zamanda örgütün mevcut yap1 ve yeteneklerinde güçlü bir 1srarcılığının yansıması olarak örgütsel atalete neden olmaktadır. Kuşkusuz bu durumun üstesinden zengin ve çeşitli bakış açılarının geliştirilmesi ve çözüm önerilerinin denenmesiyle gelinmektedir (Bakan vd., 2017: 124). Diğer yandan, örgüt içerisindeki ilişkilerde sınırlı rol, yetki, iş bölümü, sorumluluk üstlenmeme, yetersiz işbirliği ve takım çalışmasının yeterince gelişmemesinin sebep olacağı atalet durumu, alınan kararlara çalışanların katılımın sağlanması, bürokratik uygulamaların gevşetilmesi ve işbirliklerinin arttırılmasıyla engellenebilmektedir (Arl1 vd., 2012: 82).

Örgütsel atalet, yenilik isteğini olumsuz olarak etkilemekte ve örgütün sıradan bir davranış sergilemesine yol açmakta, örgütün varlığını olumsuz etkilemekte ve yüksek rekabet ortamında örgütün avantajını zayıflatmaktadır. $\mathrm{Bu}$ nedenle, bir örgütün ataletin olumsuz etkilerinden kaçınabilmesi için bilgiyi verimli ve etkili bir şekilde kullanması gerekmektedir (Fettahlığlu vd., 2018: 45).

Örgütlerin ataletten kurtulmaları konusunda Japon örgütler tarafından "J-form" olarak adlandırılan model geliştirilmiştir. "J-form" örgütleri esneklik ve takım dinamiği ile bürokrasinin istikrar ve etkinliğini birleştiren yapılar olarak tanımlamıştır. Böylece yenilikçi ve dış çevreye kolayca uyum sağlayan bir yapının meydana getirilerek örgütlerin daima formda kalmaları sağlanmıştır. Örgütsel ataletten kurtulmanın en etkin kısa yolu örgütlerin daha esnek olmalarından geçmektedir. Çünkü artık dünya pazarlarının birbirlerine daha da yakınlaşması, gittikçe daha kısa ömürlü ve geçici olmaları, örgütlerin çevreye uyum sağlama yeteneklerinin önemini daha da arttırmıştır. Diğer yandan özellikle büyük örgütlerde yaygın ve kökleşmiş kurallar ve bürokrasi ve bunun yanında değişime ayak uyduramayan eski çalışanlar da değişimi engelleyebilmekte, örgütlerdeki reformların yapılmasını zorlaştırabilmektedir. Bu nedenle örgütlerin çalışanları ile olan iletişim kalitesini üst düzeylere çıkarmaları, daha katılımcı ve paylaşımcı bir yönetim anlayışı benimsemeleri, çalışanlarını yeniliğe ve değişime teşvik etmeleri ve onlara gelecek korkusu yaşatmamaları gerekmektedir. Ayrıca örgütsel ataletin, örgütün kendi içinden gelen girişim ve talep ile aş1labileceği böylece örgütün çevresel beklentilere cevap verebilecek değişimi gerçekleştirip yeni bir yapıya kavuşabileceği söylenebilmektedir (Soysal, 2010: 24). Diğer yandan sinerjik liderliğin boyutları olan bilgi paylaşımı, vizyon, işbirliği ve ilgi örgütsel ataleti engellemektedir. Bu nedenle örgütlerde yöneticilerin örgütsel ataleti azaltmak, örgütsel verimlilik, etkinlik ve örgütsel sinerjiyi artırmak için sinerjik liderlik anlayışı benimsemeleri gerekmektedir (Yılmaz vd., 2014: 1058). Ayrıca örgütsel ataletin üstesinden gelmeye yönelik yapılan araştırmalar örgütsel ataleti engellemek için çeşitli çözüm yolları ve çözüm modelleri sunmuşlardır. Bu çözüm yolları ve çözüm modellerinden bazıları aşağıda açıklanmaktadır.

Godkin ve Allcorn (2008: 88-91) örgütsel ataletin üstesinden gelmeye yönelik bir model geliştirmişlerdir. Model; sezgisel kazanım, eylemsel oryantasyon ve değişime psikolojik hazırlık olmak üzere üç faktörden oluşmaktadır. 
-Sezgisel kazanım: Sezgisel atalet, zamanında-etkili gerçeklik testi ve uygulanabilir bilgi üretimi için birçok başarısızlık, tıkanma ve çarpılmalara neden olmaktadır. Birçok araştırmacıya göre sezgisel ataletten kurtulmanın iki yolu bulunmaktadır. Bunlar; çift döngü öğrenme ve reflektif uygulamadır. Çift döngü ögrenme, çarpitmalar, yanlış anlamalar, sıklıkla sorgulanamayan, anlaşılmaz ve statik dünyayı anlamak için kabul edilen davranışlarla ilgili temel varsayımların her zaman incelenmesinin önemi ile ilgilidir. Odayı önceden ayarlanmış sıcaklıklarda 1sıtıp soğutan bir oda termostatı gibidir. Reflektif uygulama ise durumlar karmaşık, benzersiz ve belirsiz olduğunda bilgilendirilmiș eylemde bulunma olasılığını arttıran bir uygulamadır. Reflektif uygulama, ikilemler ve çelişkiler hakkında yeni bakış açıları elde etmek için yalnızca yaşamak yerine deneyimleri inceleyerek yapılan deneyimleri ve kendi deneyimlerinden öğrenmeyi içermektedir.

-Eylemsel oryantasyon: Eylemsel atalet, yönetimle ilgili bilgilerin çok geç toplandığı ve örgütün değişen koşullara çok yavaş ayak uydurduğu durumlarda ortaya çıkmaktadır. Yönetimin varsayımları ve öncülleri, çevresel değişimin zamanında doğru bir şekilde anlaşılmasını engellemektedir. Eylemsel ataletin üstesinden gelmenin çapraz fonksiyonel gruplar ve sistematik problem çözme-öncül kontrol olmak üzere iki yolu bulunmaktadır. Çapraz fonksiyonel gruplar; yönetimin varsayımları ve önyargılarının, grup, bölüm veya meslek dışındaki kişiler tarafindan kolayca tespit edilebileceğini ifade etmektedir. Örneğin; gelir açığı, bir Chief Financial Officer (CFO)'in bakış açısına göre, maliyetlerin çok yüksek olmasından kaynaklanırken, operasyondaki bir kişi sorunu çok az satış olarak görebilmektedir. Bu nedenle eylemsel ataletten kurtulmak için çapraz fonksiyonel gruplar arasında görüş alışverişinin yapılması gerekmektedir. Sistematik problem çözmeöncül kontrol ise sistematik bir problem çözme stratejisidir. Yukarıdaki gelir açığı örneğinde, temel unsur, sorunun nasıl tanımlandığıdır. Çok fazla maliyet, çok az gelir anlamına gelmektedir. Dikkatli problem tanımı kritik ilk adımdır. Tam olarak yanlış olan nedir? Katkıda bulunan faktörler nelerdir ve ne ölçüde katkıda bulunmaktadırlar? Birbirleriyle ilişkileri nedir? Sistematik problem çözme stratejisi, doğası gereği, işin nasıl tasarlandığı ve yönetildiğini sorgulamanın kabul edilebilir olmasını sağlamaktadır.

-Değişime psikolojik hazırlık: Psikolojik değişimin önündeki engeller, işyerinde psikolojik gerilemeye ve psikolojik olarak savunucu tepkilere yol açan aşırı kaygıyı teşvik eden üzücü bir deneyimden kaynaklanmaktadır. Bunlardan kaçınmanın lider/örgütsel sınırlama ve geçiş alanı-zaman olmak üzere iki yolu vardır. Lider/örgütsel sınırlama: Örgütler ve liderler, üyelerin öngörülen saldırganlık ve kaygıları için sıklıkla bir durdurma işlevi sunarlar. Örgütsel liderler üyelerin saldırganlığını ve kaygılarına durduramazlarsa, psikolojik gerileme bireysel ve grup psikolojik savunma mekanizmalarıyla birlikte ortaya çıkar. Bu durumu durmak için liderlerin değişsimi teşvik etmeleri ve güçlü bir örgüt kültürü oluşturmaları gerekmektedir. Geçiş alanı-zaman: Örgüt üyeleri sık sık kaygılarını aşmakta başarısız olurlar ve sahte bir sığınak ararlar. Onlar, güvensizliklerini, tünel vizyonu, kıskançlık, rekabet, yıkıcılık ve kişilerarası ihtilaf gibi çeşitli biçimlerde ve modası geçmiş uygulamalara, değerlere, amaçlara ve yöntemlere tutunmak gibi mantıksız davranış tarzlarını savunmak suretiyle ifade ederler. Beklenen bu olumsuzluklardan kurtulmak için yöneticilerin geçişsel liderlik tarzı benimsemeleri önerilmektedir. Geçişsel liderlik, örgüt üyelerinin düşünce ve eylemde araştırma yapmak için özgürlük kullanabilecekleri potansiyel alanı içeren, yeterince güvenli bir bağlam oluşturan en uygun işbirliğini teşvik etmektedir.

Huang vd. (2013: 990-991) örgütsel ataletin üstesinden gelmek için inovasyon odaklı bir model geliştirmişlerdir. Modele göre örgütsel atalet, iş modeli inovasyonu ve inovasyona açık olma üzerinde olumsuz bir etkiye sahiptir. İnovasyona açı olma iş modeli inovasyonu ve örgüt performansı üzerinde olumlu bir etkiye sahiptir. İş modeli inovasyonu ise örgüt performansı üzerinde olumlu bir etkiye sahiptir. Buna göre inovasyona açık olma ve iş modeli inovasyonun örgütsel ataleti azalttığ1 
örgüt performansını artırdığı söylenebilir. Bu durumda örgütsel ataleti engellemek için örgütlerde inovasyonu teşvik edici uygulamalara yer verilmesinin faydalı olacağı düşünülmektedir.

\section{Sonuç ve Öneriler}

Atalet, yalnızca bireylerin yaşamında yer alan bir olgu değil, aynı zamanda örgütlerin yaşamında da yer almaktadır. Örgütlerde yer alan atalet örgütsel atalet olarak kavramsallaştırılmaktadır. Örgütsel atalet; örgütlerin işlemez hale gelmeleri, kendilerini yenileyememeleri, değişimlere uyum sağlayamamaları, yeniliklere açı olmamaları, mevcut durumu korumak istemeleri ve harekete geçememeleri olarak tanımlanabilir. Örgütsel atalet, örgütlerin yaşamını olumsuz etkileyen etkenlerin başında gelmektedir. Örgütsel atalet, örgütsel değişimlerin ve yeniliklerin önünde büyük bir engeldir. Değişim ise örgütler için stratejik bir öneme sahiptir. Dolayısıyla örgütsel atalet, stratejik yönetimi olumsuz etkilemektedir. Richard Rumelt’e göre örgütsel atalet; mevcut örgütsel yap1 ve fonksiyonlarda güçlü bir şekilde 1srarc1 tutumdur. $\mathrm{Bu}$ 1srarcı tutumun; bozuk alg1, körelmiş motivasyon, başarısız yaratıcı karşılıklar, örgütsel politik çıkmazlar ve eylem kesintileri olmak üzere 5 kaynağı bulunmaktadır. Örgütlerin stratejik yönetim faaliyetleri etkin ve verimli yürüterek değişime ayak uydurabilmeleri ve rekabet ortamında ayakta kalabilmeleri için örgütsel atalete neden olan bu kaynakların ortadan kaldırılması gerekmektedir (Durgun, 2018: 1).

Örgütlerin örgütsel ataletten kurtularak değişimi yönetebilecek değişken bir yapıya kavuşabilmeleri için sinerjik bir kültür oluşturmaları gerekmektedir. Sinerjik bir kültür oluşturabilen örgütler; bilgi üretme ve yetenek transferi gerçekleştirme ve bunları üretim sürecinde kullanabilme becerisi kazanmış olmaktadırlar (Tutar, 2007: 156-157). Bu bağlamda yapılan araştırmalar sinerjik liderliğin örgütsel adaleti engellediğini göstermektedir. Bu nedenle yöneticilerin, örgütte sinerjik bir kültür ve iklim oluşturarak örgütsel verimliliği ve etkinliği artırmak ve örgütsel ataleti en düşük düzeye indirgemek için sinerjik liderlik davranışları göstermelerinin örgütsel başarı açısından oldukça faydalı olacağ1 düşünülmektedir. Sonuç olarak; örgütlerin, örgütsel ataletin üstesinden gelebilmeleri için yenilikleri takip etmeleri ve değişime uyum sağlamaları, demokratik, katılımcı ve etik bir yönetim anlayışı benimsemeleri, örgüt içinde adaleti tesis ederek iç huzuru sağlayarak çalışanlarını mutlu etmeleri, değişimler ve yenilikler konusunda çalışanlarına bilgilendirici eğitimler vermeleri gerekmektedir. Ayrıca örgütsel ataletin üstesinden gelmek için yöneticilerin örgütlerde yeniliği, değişimi, işbirliği ve öğrenmeyi teşvik edici uygulamalara yer vermeleri ve güçlü bir örgüt kültürü oluşturmaları önerilmektedir. Örgütsel ataletin engellenmesi, örgütün yeniden harekete geçmesini sağlayarak örgüt performansını artıracak dolayısıyla örgütsel başarıya olumlu yansıyacaktır. Bu çalışmada örgütsel atalete yönelik teorik bir çerçeve çizilmeye çalış1lmıştır. Bundan sonraki çalışmalarda görüşme ve anket yöntemlerinin birlikte kullanıldığı nitel-nicel bir çalışmanın yapılmasının literatüre katkı sağlayacağı düşünülmektedir.

\section{Kaynakça}

Arl1, D., Ölmez Ceylan, Ö., \& Akduman Yetim, S. (2012). İlköğretim Okulu Yöneticilerinin Örgütsel Atalete İlişkin Görüşleri. Ege Eğitim Dergisi, 13(1), 73-91.

Atalay, M. (2013). Kurumsal Ataletin Yabancılaşma ve İşten Ayrılma Niyetine Etkisi. Yüksek Lisans Tezi, Afyon Kocatepe Üniversitesi Sosyal Bilimler Enstitüsü, Afyon.

Bakan, İ., Sezer, B., \& Kara, C. (2017). Bilgi Yönetiminin Örgütsel Çeviklik ve Örgütsel Atalet Üzerindeki Etkisi Bir Alan Araştırması. Kahramanmaraş Sütçü İmam Üniversitesi İIBF Dergisi, 7(1), 117-138. 
Cırcır, B. (2006). Öğretmen Adaylarının Denetim Odakları ve Mükemmelliyetçilik Tutumlarının Bazı Özlük Niteliklerine Göre Karşılaştırmalı olarak İncelenmesi. Yüksek Lisans Tezi, Selçuk Üniversitesi Sosyal Bilimler Enstitüsü, Konya.

Çankaya, İ. H. (2010). İlköğretim Okul Yöneticilerinin Vicdan Odaklı Yaklaşım Düzeyleri İle Atalet Algıları Arasındaki İlişki. Ahi Evran Üniversitesi Eğitim Fakültesi Dergisi, 11(2), 65 74.

Çankaya, İ. H., \& Demirtaş, Z. (2010). Öğretmen Adaylarının Görüşlerine Göre Üniversite İklimi ve Atalet Arasındaki İlişki. Pamukkale Üniversitesi Eğitim Fakültes Dergisi, 2(28), 1-9.

Durgun, M. (2018). Örgütsel Atalet ve Stratejik Yönetim. Yönetsel Zihin: http://www.yonetselzihin.com/stratejik-yonetim/orgutsel-atalet-ve-stratejik-yonetim/.html, Erişim Tarihi: 17.04.2019.

Erdem, B. (2006). İşletmelerde Yeni Bir Yönetim Yaklaşımı: Kıyaslama (Benchmarking). Balıkesir Üniversitesi Sosyal Bilimler Dergisi, 9(15), 65-94.

Erdil, O., Kalkan, A., \& Alparslan, A. M. (2010). Örgütsel Ekoloji Kuramından Stratejik Yönetim Anlayışına. Doğuş Üniversitesi Dergisi, 12(1), 17-31.

Fettahlıoğlu, Ö. O., Akdoğan, Z., \& Allkış, A. (2018). Örgütsel Kimlik Dejenerasyonu Üzerinde Örgütsel Atalet Algisının Etkisi. Social Mentality and Researcher Thinkers Journal, 4(8), 4354.

Godkin, L., \& Allcorn, S. (2008). Overcoming Organizational Inertia: A Tripartite Model for Achieving Strategic Organizational Change. Journal of Applied Business and Economics, 8(1), 82-94.

Huang, H.-C., Lai, M.-C., Lin, L.-H., \& Chen, C.-T. (2013). Overcoming Organizational Inertia to Strengthen Business Model Innovation- An Open Innovation Perspective. Journal of Organizational Change Management, 26(6), 977-1002. doi:10.1108/JOCM-04-2012-004.

İbrahimoğlu, N., Seyhan, M., \& Bal, F. (2015). Teknofobi Düzeyi ve Örgütsel Atalet İlişkisi: Gaziantep İli Kamu Hastanelerinde Bir Araştırma. 3.Örgütsel Davranış Kongresi, (s. 615620). Tokat.

Kaya, Ş. D., Yüceler, A., \& Yağcı Özen, M. (2018). Hemşirelerde Atalet Davranışları ve Hasta Güvenliği. Nobel Medicus, 14(2), 40-48.

Kinnear, C., \& Roodt, G. (1998). The Development Of An Instrument For Measuring Organisational Inertia. Journal of Industrial Psychology, 24(2), 44-54.

Koçel, T. (2010). İşletme Yöneticiliği. İstanbul: Beta Yayıncılık.

Önder, Ç., \& Üsdiken, B. (2007). Örgütsel Ekoloji: Örgüt Toplulukları Ve Çevresel Ayıklama. Örgüt Kuramları. Ankara: İmge Kitabevi.

Özen Kutaniş, R., \& Dikili, A. (2012). Değişim Boyutuyla Örgütlerde Sinisizm. N. D. Ergun Özler içinde, Örgütsel Davranışta Güncel Konular (s. 269-285). Bursa: Ekin Yayınevi.

Sekman, M., \& Utku, A. (2009). Çevik Şirketler: Kurumsal Ataleti Yenmek. İstanbul: Alfa Yayınlar1.

Soysal, A. (2010). Atalet: Etkin Yönetim İçin Kişisel ve Örgütsel Düzeyde Bir Analiz. Çimento İşveren Sendikası Dergisi, 24(3), 16-26.

Şahlan, G. (1979). Bürokratik Sistemlerde Yönetime Katılma Olgusu ve Yapısal Sinırlılıklar. Amme İdaresi Dergisi, 19-32. 
Şenturan, Ş. (2007). Mesleki Yabancılaşma: Kamu Bankalarında Yeniden Yapılandırma Sonucu Çeşitli Kurumlara Aktarılan Çalışanların Durumu. Kamu-İş Dergisi, 9(1), 91-104.

TDK. (2006). Güncel Türkçe Sözlük. http://www.tdk.gov.tr/index.php?option=com_gts\&arama=gts\&guid=TDK.GTS.5cb584d61ff c67.74784806, Erişim Tarihi:16.04.2019.

Tutar, H. (2007). Örgütsel Eylemsizliği Açıklama Aracı Olarak Öğrenilmiş Çaresizlik, "İş, Güç" Endüstrü İlişkileri İnsan Kaynakları Dergisi, 9(4), 142-161. do1: 10.4026/13032860.2007.0058.X

Yeğin, A., \& Badıllı, A. (1981). Osmanlıca-Türkçe Ansiklopedik Büyük Lugat. İstanbul: TÜRDAV Yayınları.

Yılmaz, A., Çelik, A., Abul, A., \& Nalçın, A. Z. (2014). Sinerjik Liderler Örgütsel Ataleti Yener Mi? Çalışanların Özyeterliliğinin Aracılık Etkisi. 22. Ulusal Yönetim ve Organizasyon Kongresi, (s. 1051-1060). Konya. 